\title{
Professionalism as a personal priority of a higher school teacher and a condition for high- quality training of a graduate
}

\author{
Svetlana Sergeeva ${ }^{1 *}$, Olga Vagaeva $^{1}$, Yulia Dianova $^{1}$, Mikhail Denisov $^{1}$, and \\ Olga Voskrekasenko \\ ${ }^{1}$ Penza State Technological University, Department of Pedagogy and Psychology, Penza, Russia \\ ${ }^{2}$ Penza State University, Department of Pedagogy and Psychology, Penza, Russia
}

\begin{abstract}
The professionalism of a higher school teacher and the quality of their work largely determine the quality of training of future graduates who are ready for professional advancement in the context of the development of new high-tech technologies and the increasing demands of partners in the real sector of the economy. In this regard, the research aims to find ways and mechanisms to improve the professionalism of the teacher, their training, and retraining in contemporary educational practice. The article presents the research results obtained at the Department of Pedagogy and Psychology of Penza State Technical University (Penz STU) on the concerned problems. The novelty of the research lies in the effective ideas, approaches, and principles of constructive problem-solving in educational practice proposed based on the analysis of normative, historical, pedagogical, and scientific literature of foreign (Germany, Great Britain, and the USA) and domestic practices. It is shown that the studied and characterized models of improving the professionalism and training of academic staff in higher education, identified leading principles underlying the implementation of these models, and the relationships among the goals, results, and conditions of training and retraining of academic staff in the realities of today can be in demand and successfully implemented. As promising areas for improving the professionalism of a higher school teacher to effectively address issues of high-quality training of graduates, the authors offer to provide pedagogical support as the most productive technology to support a novice teacher during their professional adjustment, conducting monitoring of the effectiveness of teachers' activities to improve the quality of their professionalism, and encouraging effective and efficient work, as well as providing social partnership and integration of all types of educational resources.
\end{abstract}

Keywords: teacher, teacher's performance efficiency.

* Corresponding author: sergeeva@pgta.ru 


\section{Introduction}

Today, higher school teachers are actively involved in the development of new advanced interdisciplinary export-oriented educational programs of higher education and their individual disciplines (modules). For a successful solution of the tasks they face, the professionalism of a higher school teacher acquires an important social significance. This is because the quality of professional activities carried out by teachers largely determines the effectiveness of training future specialists $[1,2]$.

To respond quickly to changes in the internal and external environment, including those that occur in the labor market, it is important for teachers to systematically improve their professionalism. The focus on solving this problem is also declared in the National Doctrine of Education of the Russian Federation for the period up to 2025.

Issues of professionalism as a personal priority of a teacher, as well as their training and retraining, are traditional in Russian pedagogical science. However, the growth of requirements for the quality of qualifications and professionalism of higher school teachers focuses researchers on further search for ways and mechanisms to improve them.

The novelty of the research lies in the proposed constructive ideas (corporate education, free choice), approaches (network-based, and individual) and principles (innovation orientation, and educational and innovative development, multilevel interaction and partnership, permanent nature of training, responsive content of training courses, etc.) of improving the professionalism of a higher school teacher, their training and retraining.

The research aims to find ways and mechanisms to improve the professionalism of a higher school teacher. The main tasks are searching for ways and mechanisms to improve the professionalism of higher school teachers, their training and retraining based on educational practices gained abroad and in Russia, as well as presenting possible solutions to the problem at the current stage, based on the analysis of scientific literature.

\section{Methods}

Methods of analysis and synthesis of historical, pedagogical, and scientific literature were used to perform the tasks set. The literature was selected according to the main research issues. The source base of the research included normative documents, historical and pedagogical, scientific and methodological materials corresponding to the period from the mid-twentieth century to the present.

\section{Results}

From 2006 to the present, the Department of Pedagogy and Psychology of Penz STU, under the guidance of Prof. S.V. Sergeeva, has been researching issues related to the professionalism of scientific and pedagogical personnel, their training, and retraining abroad and in Russia, as well as supervising studies of defended Ph.Ds in pedagogical sciences.

Summarizing the data obtained in the course of the study, one can state that several ideas, approaches, and principles that are successfully implemented in foreign practice (Great Britain, Germany, and the USA) concerning professional development and retraining of scientific and pedagogical personnel of higher education are quite effective.

Consider some of them. In Germany, this is creating of innovation-oriented and successfully functioning higher school didactics centers incorporated in networks and complexes, which are based on a multilevel system of professional development, responsive and variable models of content implementation that are personal, and practice- 
oriented, taking into account the peculiarities of the motivational sphere of the teacher, as well as active international cooperation and internships (T.A. Piterskova) [3].

In Great Britain, the success is caused by effective functioning based on the ideas of corporate education and a network approach of various organizations that implement practice-oriented models of professional development of teachers (Ye.V. Kozlova) [4]. Among principal corporate approaches, identified by Ye.V. Kozlova, one should note "the dependence of the organization and content of advanced training on the goals and educational policy of the university; permanent learning; responsive course content; advancement and focusing on results" [5]. The principles of the network approach identified by Kozlova are "progressive and innovative development; the presence of a common goal, partnership; and multilevel interaction" [5].

In the USA, these are ideas implemented in the course of professional development of teachers to freely choose from state-supported research programs (grants), responsive courses and programs, consultants in the concerned problem area, as well as working time management to improve and enhance professionalism (Yu.N. Kulikova) [6]. The individualistic approach, identified in the course of the study conducted by Kulikova, is of particular interest in terms of the personality-oriented advanced training courses, independence of teachers in solving professionally significant tasks, supporting them by faculty developers in case of difficulties and when determining ways to overcome them [7].

In addition to the study of foreign experience, the authors examined also the domestic experience of professional development and training of higher school teachers. Thus, the research of O.A. Yurmasheva (Vagaeva) offers the solution to the problem associated with the search for ways to improve the professionalism of a higher technical school teacher [8]. The studied and characterized models of training teachers in a technical university, the identified main principles underlying the implementation of these models, as well as the relationships among the goals, results, and conditions of higher school teachers' training are quite noteworthy.

Currently, research on professional development as a personal priority of higher school teachers is continuing. They are related to monitoring the effectiveness of their activities to improve quality and encourage teachers to work effectively [9]. Thus, since 2017, PenzSTU has been carrying out comprehensive planning, monitoring, and evaluating the effectiveness of teachers' activities, as well as implementing a system of basic and key indicators being updated annually. With the active participation of researcher Yu.A. Dianova, a graduate student of the Department at PenzSTU, an electronic form of the portfolio of a teacher was developed to present the results of performance indicators [10]. Monitoring, as a way of systematic reflection of one's own activities, contributes to the development of the professional skills of a teacher [11].

In the course of solving problems related to improving the professionalism of scientific and pedagogical personnel, a significant role is given to the issues of adaptation of novice teachers $[12,13]$. Thus, O.A. Voskrekasenko, carrying out a wide range of studies on adaptation issues, concludes that the most productive technology for supporting a novice teacher during their professional adaptation is pedagogical support [14]. It allows solving the following tasks: creating psychologically comfortable conditions for the professional activity of a young specialist; providing comprehensive assistance in resolving difficulties that arise in the course of their professional activities; attracting experienced specialists from among the teaching staff to assist a novice teacher; and creating conditions for their professional and career growth. Comprehensive support for the professional adaptation of a novice teacher allows solving the problem of rejuvenation of the teaching staff without compromising the quality of professional training of future graduates.

Improving the professionalism of higher school teachers is largely determined by their interaction with social partners. This is due to the practice-oriented nature of the 
educational process $[16,17]$. The problem of interaction between educational organizations and enterprises in the course of practice-oriented training of students is studied by M.V. Denisov, a graduate student of PenzGTU [18]. As the main areas of social partnership, he defines updating the content of education at the stage of development of educational planning documentation and joint assessment of the quality of professional training of university graduates. Denisov believes that in the framework of the first area, the involvement of teachers and employer's representatives in career guidance, holding round tables, as well as scientific and practical conferences are very important. As part of the second area, Denisov considers attracting employers to intermediate certification and state final certification [19]. In his research, Denisov concludes that the social partnership between teachers and representatives of employers allows not only developing mechanisms for coordinating the content of education according to the requirements of contemporary high-tech production but also increasing the professional competence of teachers by increasing their level of proficiency in modern means of solving professional problems of real production [18].

\section{Discussion}

The analysis of the obtained data shows that the problem of professionalism as a personal priority of a higher school teacher is discussed by contemporary domestic researchers more often than the problem of teachers' training and retraining. The availability of just several Ph.D. and Doctoral dissertation theses is quite indicative of this fact. At the same time, the analysis of foreign literature reveals high interest in this problem shown not only by researchers and practitioners but also by government officials, since in the global sense of the word, the effectiveness of university teachers depends largely on their professionalism, while high-quality education in today's reality is regarded as an essential condition for the national security.

\section{Conclusion}

To respond quickly to changes in the internal and external environment, including those that occur in the labor market, a higher school teacher needs to be in demand and be competitive. In this regard, it is important for the teachers to systematically improve their professionalism, which determines the quality of professional training of future graduates. According to the authors, improving the professionalism of a higher school teacher should be carried out using ideas of corporate education, free choice, network-based and individual approaches, as well as the principles of their implementation, such as pedagogical support as the most productive technology to support novice teachers during their professional adaptation, monitoring the effectiveness of teachers, as well as social partnership and integration of all types of educational resources.

\section{References}

1. S.V. Sergeeva, O.A. Voskrekasenko, Ye.V. Kozlova, The Social Sciences, 11(25), 6124-6128 (2016)

2. I.I. Orlova et al., Amazonia Investiga, 9(26), 341-348 (2020)

3. T.A. Piterskova, Izvestiya vysshikh uchebnykh zavedeniy. Povolzhskiy region, 3(11), 177-185 (2009)

4. Ye.V. Kozlova, Modern problems of science and education, 6, 231 (2013) 
5. Ye.V. Kozlova, Formation and development of the system of advanced training of scientific and pedagogical personnel of universities in Great Britain (from the mid 60s of the XX century to the beginning of the XXI century) (Saratov, 2014)

6. Yu.N Kulikova, S.N. Volkov, XXI vek: itogi proshlogo i problemy nastoyashchego plyus, 2(1), 79-84 (2015)

7. Yu.N. Kulikova, XXI vek. Chelovek i okruzhayushchiy mir, 2(02), 131-140 (2018)

8. N.M. Galimullina, O.A. Vagaeva, D.E. Lomakin, T.E. Melnik, A.V. Novakovskaya, Journal of Physics: Conference Series 1515, 0220203 (2020)

9. O.I. Pometun, N.M. Gupan, Humanitarian Balkan Research, 1, 60-63 (2018)

10. T.V. Guskova, Yu.A. Dianova, Portfolio of a teacher as a presentation of the results of his professional activity, in Development of lifelong education in a technical university as a multilevel educational complex: materials of an international scientific and practical conference, 29 May 2017, Penza, Russia (2017)

11. S.V. Danilov, M.I. Lukyanova, I.V. Aryabkina, Amazonia Investiga, 9(28), 30-41 (2020)

12. A.R. Alaverdov, T.P. Alaverdova, Higher education in Russia, 4, 5-16 (2016)

13. I.A. Karpovich, L.S. Voronova, Azimuth of Scientific Research: Pedagogy and Psychology, 9(2(31)), 106-110 (2020)

14. O.A. Voskrekasenko, Pedagogical support in the categorical apparatus of science, in Philosophy of education in the national cultural and historical tradition: history and modernity: a collection of articles of the VI All-Russian scientific and practical conference. 13-14 February 2020, Penza, Russia (2020)

15. P. Grossman, C.G.P. Dean, S.S. Kavanagh, Z. Herrmann, Phi Delta Kappan, 100(7) (2019)

16. K.M. Black, Journal of Engineering Education, 83(1), 26-28 (1994). https://doi.org/10.1002/j.2168-9830.1994.tb00112.x

17. O.I. Vaganova, I.N. Odarich, O.A. Rudakova, Ju.S. Volkova, M.N. Bulaeva, Amazonia Investiga, 9(28), 42-49 (2020)

18. S.N. Volkov, M.V. Denisov, V.V. Zemlyansky, XXI vek: itogi proshlogo i problemy nastoyashchego plyus, 2(1(23)), 51-56 (2015)

19. N.V. Kamenez, O.I. Vaganova, Z.V. Smirnova, L.I. Kutepova, I.V. Vinokurova, Amazonia investiga, 8(18) (2019) 